\title{
Dinamika Kontrol Diri pada Ibu Bekerja yang Menjalani Latihan Yoga
}

\author{
Kadek Anindita Widyasari dan I Gst Ayu Diah Fridari, S.Psi, M.Psi, Psikolog \\ Program Studi Psikologi, Fakultas Kedokteran, Universitas Udayana
}

\begin{abstract}
Abstrak
Dewasa ini semakin banyak Ibu yang memutuskan untuk bekerja baik bekerja paruh waktu maupun berkarir secara penuh. Menurut Encyclopedia of Children's Health, Ibu bekerja adalah suatu keadaan dimana seorang Ibu bekerja di luar rumah untuk mendapatkan penghasilan disamping membesarkan dan mengurus anak di rumah. Adapun penggolongan seorang wanita yang dapat dikatakan sebagai Ibu bekerja adalah wanita yang memiliki anak dengan rentang usia 0-18 tahun dan menjadi tenaga kerja (Lerner, 2001). Pada tahun 2001, diketahui bahwa jumlah Ibu yang bekerja di seluruh dunia mencapai 54,3\% (OECD, 2001) dimana peran ganda wanita sebagai Ibu rumah tangga dan pencari nafkah semakin dibutuhkan seiring dengan kemajuan teknologi saat ini. Menurut Bower (dalam Reynolds et. al, 2003) selain faktor ekonomi, partisipasi para Ibu di lapangan kerja juga dipengaruhi oleh faktor sosial, politik dan demografi. Kontrol diri menjadi satu faktor penting bagi para Ibu karena keputusan seorang Ibu dalam bertindak saat menghadapi berbagai keadaan sedikit tidaknya akan berpengaruh pada suasana rumah tangga itu sendiri. Kesadaran akan pentingnya kontrol diri ini akan membuat para Ibu berusaha untuk meningkatkan kualitas kontrol dirinya, salah satunya adalah dengan melakukan latihan Yoga.

Penelitian ini menggunakan metode kualitatif dengan desain fenomenologi. Subjek yang digunakan dalam penelitian ini sebanyak tiga orang Ibu bekerja. Hasil penelitian memperlihatkan bahwa terdapat peningkatan kualitas kontrol diri pada Ibu bekerja yang melakukan latihan Yoga dilihat dari aspek kontrol perilaku, kontrol kognitif dan decisional control serta proses Yoga asana, pranayama dan meditasi dalam sesi latihan Yoga.
\end{abstract}

Kata kunci: Kontrol Diri, Ibu bekerja, Yoga

\begin{abstract}
Nowadays, the number of mother worked increasingly increased either as a part-time or full time worker. In Encyclopedia of Children's Health, working mother is a situation where a mother working outside the home to earn income in addition to taking care of children at home. The classification of working mother is a woman who has children ranging in age from 0-18 years and a workforce (Lerner, 2001). On 2001, number of working mothers in the world reached 54,3\% (OECD, 2001), which is the dual role required along with current technological advances. Beside economic factors, the mother's participation in employment is also influenced by social, political and demographic (Bower, on Reynolds et. al, 2003). In this case, self-control is important because the decision of a mother to act in the face of variety of circumstances few would least affect the atmosphere of the household itself. Awareness of the importance of self-control will make the mother trying to raise her self-control, one of which is doing Yoga exercises.

This study use qualitative method and phenomenological approach, with 3 of working mother. The result show that there is an increase in the quality of self-control on working moms who do Yoga exercises seen from the aspect of behavioral control, cognitive control, decisional control and the process of Yoga asana, pranayama and meditation in the Yoga session
\end{abstract}

Keywords: self-control, working mother, yoga 


\section{LATAR BELAKANG}

Sejak dini seorang anak perempuan seringkali diberikan berbagai tugas dalam pekerjaan rumah dan ini terus berlanjut hingga ia dewasa. Diantara berbagai peranan tersebut, salah satu tugas paling mulia yang akan dialami oleh sebagian besar wanita adalah tugas sebagai seorang Ibu.

Ibu merupakan sosok penting yang terdapat dalam struktur suatu keluarga. Seperti yang kita ketahui, menjadi seorang Ibu bukanlah perkara mudah dimana seorang Ibu seringkali mengambil berbagai peran dalam keluarga sesuai dengan situasi dan kondisi dalam keluarga tersebut. Dilihat dari berbagai peran dan tugas yang diemban para Ibu dapatlah kita bayangkan betapa besar kemungkinan akan timbulnya masalah dan konflik bagi para Ibu. Banyaknya kewajiban yang dipikul oleh para Ibu akan memicu timbulnya berbagai perasaan dalam diri para Ibu sehingga tak jarang membuat Ibu menjadi mudah marah, kesal, sensitif dan tidak sabaran. Berbagai perasaan yang timbul ini akan dapat mempengaruhi keadaan keluarga yang dibinanya karena peranan seorang Ibu merupakan satu hal penting dalam struktur keluarga.

Salah satu tugas Ibu yang turut mempengaruhi kondisi keluarga adalah suatu keadaan dimana Ibu tersebut bekerja. Menurut Lerner (2001) dalam Encyclopedia of Children's Health, Ibu bekerja adalah suatu keadaan dimana seorang Ibu bekerja di luar rumah untuk mendapatkan penghasilan disamping membesarkan dan mengurus anak di rumah. Adapun penggolongan seorang wanita yang dapat dikatakan sebagai Ibu bekerja adalah wanita yang memiliki anak dengan rentang usia 0-18 tahun dan menjadi tenaga kerja.

Banyaknya Ibu yang memutuskan untuk bekerja ini dapat dilihat dari meningkatnya persentase Ibu bekerja dimana pada tahun 2001 diketahui bahwa jumlah Ibu yang bekerja di seluruh dunia mencapai 54,3\% (OECD, 2001). Salah satu penyebab meningkatnya jumlah wanita yang mengambil peran ganda sebagai Ibu rumah tangga dan pencari nafkah dewasa ini salah satunya disebabkan oleh kemajuan teknologi saat ini. Menurut Bower (dalam Reynolds et. al, 2003) selain faktor ekonomi, partisipasi para Ibu di lapangan kerja juga dipengaruhi oleh faktor sosial, politik dan demografi. Dalam hal ini kondisi sosial dan lingkungan tempat tinggal para Ibu tersebut juga membawa pengaruh bagi keputusan Ibu untuk bekerja. Sebagai contoh, jika seorang wanita tinggal dalam kalangan pengusaha maka kemungkinan besar individu tersebut akan memutuskan untuk menjadi wanita karir. Disamping itu, faktor pendidikan juga turut berpengaruh dalam keputusan seorang Ibu untuk bekerja dimana semakin tinggi pendidikan seorang wanita maka semakin besar pula keinginannya untuk mengaplikasikan pengetahuan itu dalam dunia karir. Dengan paparan diatas dapat kita bayangkan betapa mudahnya perasaan seorang Ibu berubah sesuai dengan kondisi yang dialami para Ibu saat itu.
Kesabaran dalam hal ini menjadi satu faktor penting dengan kondisi banyaknya peranan yang dipikul para Ibu dan rentannya seorang Ibu dari sebuah konflik karena hal ini kerap menyebabkan seorang Ibu menjadi kurang sabar dan gampang marah dalam menghadapi berbagai permasalahan yang terjadi di lingkungannya. Dengan demikian pentinglah bagi seorang Ibu untuk dapat mengontrol dirinya sendiri agar tidak sampai lepas kendali dalam menghadapi setiap masalah yang terjadi dalam hidupnya.

Kontrol diri adalah kemampuan untuk menangguhkan kesenangan naluriah langsung dan keputusan untuk memperoleh tujuan masa depan yang biasanya dinilai secara sosial (Harre dan Lamb, 1996). Jadi dapat dikatakan bahwa kontrol diri adalah suatu keadaan dimana seseorang dapat membuat keputusan dan mengambil tindakan yang efektif untuk menghasilkan akibat yang diinginkan dan menghindari akibat yang tidak diinginkan. Hal ini penting dilakukan bukan hanya karena menyangkut diri Ibu itu sendiri melainkan juga akan membawa pengaruh bagi keadaan rumah tangga yang dibinanya maupun kehidupan sosial Ibu tersebut. Seorang Ibu yang dapat mengontrol diri dengan baik akan dapat menentukan pilihan-pilihan dengan mempertimbangkan berbagai konsekuensi dari pilihan tersebut. Pilihan yang diambil oleh para Ibu ini tak jarang berhubungan dengan keinginan pribadi mereka baik pilihan itu sesuai maupun bertolak belakang dengan keinginan tersebut..

Salah satu faktor yang berhubungan dengan kemampuan kontrol diri para Ibu adalah faktor kesehatan. Menjaga kesehatan penting untuk dilakukan para Ibu karena selain untuk dirinya sendiri juga penting bagi orang-orang disekitarnya mulai dari keluarga hingga orang-orang dalam lingkungan sosialnya. Adapun pengertian sehat yang dikemukakan oleh Organisasi Kesehatan Dunia (WHO) pada tahun 1975 adalah bahwa sehat adalah suatu kondisi yang terbebas dari segala jenis penyakit baik fisik, mental dan sosial (WHO, 2010). Jadi kesehatan yang dimaksud disini tidak hanya semata-mata kesehatan fisik namun juga kesehatan psikis dimana keseimbangan antara keduanya dapat membuat keadaan diri seorang Ibu menjadi lebih utuh dan mantap.

Keseimbangan antara kesehatan fisik dan psikis dapat diperoleh dengan berbagai cara. Salah satu cara yang dapat dilakukan untuk mendapat keseimbangan fisik dan psikis adalah dengan melakukan latihan Yoga. Yoga merupakan salah satu bentuk olahraga yang tidak hanya terbatas pada latihan fisik namun juga kaya akan latihan untuk pikiran dan jiwa seseorang (Somvir, 2008). Pasalnya, dalam setiap gerakan Yoga selain gerakan tubuh juga terdapat latihan nafas dan sesi relaksasi yang setara dengan meditasi dimana hal ini akan membuat pencapaian keseimbangan kesehatan fisik dan psikis ini menjadi lebih mudah karena dalam satu sesi sudah terdapat olah tubuh dan meditasi. Dengan demikian, selain mendapat tubuh yang sehat kita juga mendapat manfaat 
tersendiri untuk kesehatan psikis dalam malakukan latihan Yoga.

Disamping untuk kesehatan tubuh dan pikiran, dewasa ini terapi Yoga juga sudah mulai dikenal sebagai solusi bagi berbagai masalah psikologis. Pernyataan tersebut menjelaskan bahwa beberapa gangguan untuk jiwa seperti stres, depresi dan tingkat agresif dapat dinetralisir dengan Yoga (Somvir, 2008). Banyaknya manfaat yang ditawarkan dari latihan Yoga pada akhirnya menarik perhatian banyak orang untuk melakukan latihan Yoga secara rutin.

Terdapat beberapa manfaat yang bisa didapatkan melalui latihan Yoga diantaranya adalah dapat mengurangi ketegangan tubuh, pikiran dan mental serta membuatnya lebih kuat saat menghadapi stres. Manfaat lainnya adalah memberikan relaksasi yang mendalam bagi tubuh, meningkatkan rasa percaya diri dan meningkatkan kemampuan untuk berpikir positif (Sindhu, 2007). Berbagai manfaat ini sesuai dengan pemaparan sebelumnya dimana kesehatan yang diperlukan oleh setiap individu tidak hanya semata-mata kesehatan fisik namun juga sehat secara mental.

Beberapa contoh manfaat yang disebutkan diatas manarik perhatian peneliti dimana dalam hal ini peneliti ingin mengetahui bagaimana latihan Yoga dapat mempengaruhi seorang Ibu dalam mengontrol dirinya dalam setiap masalah yang muncul. Peneliti juga ingin melihat aspek-aspek apa saja yang mempengaruhi kontrol diri pada Ibu bekerja sehingga dapat ditemukan dinamika yang terjadi didalamnya.

Dalam penelitian ini peneliti ingin meneliti kontrol diri para Ibu khusunya para Ibu bekerja untuk melihat kompleksitas dari tugas-tugas mereka sebagai seorang Ibu dimana peneliti berpikir bahwa kemampuan kontrol diri pada seseorang Ibu merupakan salah satu faktor penting bukan hanya bagi dirinya melainkan bagi keluarga yang dibinanya. Adapun aspek-aspek kontrol diri yang ingin dilihat peneliti mencakup jenis, kualitas serta faktor-faktor yang mempengaruhi kontrol diri para Ibu bekerja tersebut. Menurut Averill (dalam Herlina, 2000) terdapat beberapa jenis kontrol diri yaitu behavioral kontrol yang merupakan kemampuan seseorang untuk mengontrol perilakunya, cognitive control yaitu kemampuan seseorang untuk mengatur pikirannya serta decisional control yaitu kemampuan seseorang untuk menentukan pilihan. Disamping itu aspek kontrol diri yang ingin dilihat oleh peneliti adalah kualitas dari kontrol diri para Ibu bekerja tersebut dimana Block dan Block (dalam Lazarus, 1976) menyatakan bahwa terdapat 3 jenis kualitas kontrol diri yaitu over control, under control dan appropriate control. Peneliti juga ingin melihat apakah para Ibu merasakan perubahan atas kontrol diri mereka sebelum dan setelah mengikuti latihan Yoga tersebut. Aspek lain dari kontrol diri yang ingin dilihat oleh peneliti adalah faktor yang mempengaruhi kontrol diri para Ibu bekerja dimana menurut Skinner (dalam Santrock, 2006) faktor pengaruh ini dapat bersumber dari dalam diri individu (internal) maupun luar diri individu (eksternal). Dengan kemampuan kontrol diri yang baik, seorang Ibu diharapkan dapat membina keluarga dengan baik sehingga pertumbuhan anak-anak serta keharmonisan keluarga dapat terjaga.

Dengan memfokuskan pada ketiga aspek kontrol diri diatas, peneliti ingin mengetahui bagaimana latihan Yoga yang dilakukan para Ibu bekerja dapat membawa pengaruh bagi kontrol diri mereka. Ketertarikan ini muncul setelah peneliti mengetahui bahwa salah satu manfaat Yoga cukup berkaitan dengan kemampuan kontrol diri seseorang, dimana peneliti berpikir bahwa para Ibu yang melakukan latihan Yoga sedikit tidaknya akan mendapatkan manfaat tersebut sehingga hal ini menarik perhatian peneliti untuk mengkaitkan dua faktor tersebut dalam penelitian ini.

\section{METODE}

\section{Tipe Penelitian}

Pada penelitian ini, peneliti menggunakan metode penelitian kualitatif dimana metode penelitian dengan jenis ini dilakukan pada setting dan objek alamiah. (Poerwandari, 1998).

Desain yang digunakan dalam penelitian ini adalah fenomenologi dimana mengacu pada pandangan Husserl dan Schutz (1984) peneliti berusaha memahami arti peristiwa dan kaitan-kaitannya terhadap orang-orang biasa dalam situasi tertentu.

Dalam penelitian ini peneliti memutuskan untuk menggunakan desain penelitian fenomenologi untuk menggali lebih dalam bagaimana dinamika kontrol diri yang dirasakan para Ibu bekerja yang telah rutin melakukan latihan Yoga. Hal yang akan dikaji mencakup perasaan, emosi, kondisi fisik hingga pendapat significant others dari para Ibu bekerja tersebut. Hal ini sejalan dengan suatu pernyataan dimana fokus penelitian fenomenologi tersebut adalah penemuan fakta dari suatu fenomena dimana peneliti berusaha untuk memahami tingkah laku manusia berdasarkan perspektif informan (Spielgelberg, dalam Streubert dan Carpenter, 1999). Menurut Spielgelbert (dalam Streubert dan Carpenter, 1999), terdapat 3 tahap dalam proses penelitian fenomenologi deskriptif yang dijadikan acuan oleh peneliti dalam penelitian kali ini yaitu:

1. Tahap intuiting : dalam tahap ini peneliti memasuki secara total dengan empati dan menghargai ungkapan informan pada fenomena yang diteliti dan merupakan proses dimana peneliti mulai tahu tentang fenomena yang digambarkan informan. Peneliti bersifat alami tanpa mempengaruhi informan.

2. Tahap analyzing : dalam tahap ini peneliti mengidentifikasi intisari fenomena tentang aspek kontrol diri pada Ibu bekerja berdasarkan data-data yang diperoleh 
dari informan. Pada tahap ini identifikasi dilakukan seteliti dan secermat mungkin untuk memperoleh keakuratan dan kemurnian hasil sesuai dengan pengamatan informan.

3. Tahap describing : tahap ini merupakan tahap terakhir dimana peneliti membuat narasi yang luas dan mendalam tentang fenomena yang diteliti. Deskripsi tulisan ini bertujuan untuk mengkomunikasikan dinamika kontrol diri yang dirasakan para Ibu bekerja yang telah rutin melakukan latihan Yoga.

\section{Unit Analisis}

Dalam penelitian ini unit analisis penelitian dibagi dalam dua tahapan, yaitu unit analisis kelompok dan unit analisis individu. Unit analisi kelompok akan peneliti lakukan pada saat peneliti mencari pandangan awal mengenai kontrol diri pada Ibu bekerja serta manfaat-mafaat dari latihan Yoga sedangkan unit analisis individu akan dilakukan saat peneliti menggali secara mendalam mengenai pengalaman, perasaan serta pandangan para Ibu bekerja yang mengikuti laitihan Yoga terkait dengan kontrol diri serta tugas-tugas sebagai sorang Ibu. Hal-hal yang digali secara mendalam akan terkait dengan aspek-aspek kontrol diri yang ingin diketahui peneliti yaitu jenis kontrol diri, kualitas serta faktor yang mempengaruhi kontrol diri para Ibu, namun ini tidak menutup kemungkinan akan ada aspek lain yang terungkap, sesuai dengan data yang diperoleh di lapangan. Unit-unit analisis ini akan diperoleh melalui proses in-depth interview dengan menggunakan panduan pertanyaan yang terkait dengan aspekaspek kontrol diri serta pandangan terhadap tugas Ibu serta pengalaman dalam menjalani latihan Yoga tersebut.

\section{Subyek Penelitian}

Subyek yang terlibat dalam penelitian ini adalah Ibu bekerja yang telah mengikuti latihan Yoga selama minimal 6 bulan. Subyek penelitian ini difokuskan pada Ibu bekerja dimana dalam penelitian ini peneliti ingin melihat kompleksitas dari para Ibu bekerja dalam menjalani tugastugasnya sebagai seorang Ibu. Adapun beberapa kriteria inklusi dari subyek penelitian ini sesuai dengan tahapan pengambilan datanya, adalah:

1. Dalam preliminary study, subyek yang digunakan berkisar 10-25 orang yang dipilih secara acak dimana tahapan ini dilakukan untuk mengetahui informasi-informasi dasar mengenai subyek serta kontinuitas latihan Yoga yang telah dijalani subyek.

2. 3 orang Ibu bekerja yang telah melakukan latihan Yoga minimal selama 6 bulan serta melakukan latihan Yoga 2-3 kali dalam seminggu diikutkan peneliti dalam tahap wawancara mendalam untuk mengetahui lebih dalam mengenai pandangan, pengalaman serta keinginankeinginan mereka terkait dengan kontrol diri, latihan Yoga serta harapan-harapan mereka yang terkait dengan tugas para Ibu.

\section{Teknik Penggalian Data}

Untuk mendapat hasil yang reliabel, peneliti menggunakan beberapa teknik penggalian data dalam penelitian ini dimana teknik pertama adalah dengan melakukan preliminary study. Preliminary Study atau yang biasa disebut dengan studi awal adalah suatu analisis singkat yang menjadi bagian dari proses negosiasi. Dalam penelitian ini preliminary study dilakukan sebagai tahapan awal untuk mencari beberapa orang untuk tahap selanjutnya. Pada pelaksanaan preliminary study ini peneliti menggunakan kuesioner yang berisi beberapa pertanyaan yang diisi oleh calon subyek. Para calon subyek yang sesuai dengan kategori yang diinginkan peneliti kemudian akan peneliti ikut sertakan dalam tahap selanjutnya.

Teknik penggalian data selanjutnya adalah dengan melakukan wawancara mendalam dimana, wawancara adalah metode pengambilan data dengan cara melakukan percakapan antara dua orang atau lebih yaitu interviewer yang akan mengajukan pertanyaan dan orang yang akan diwawancarai yang akan memberikan jawaban atas pertanyaan yang akan diajukan (Moleong, 2005). Terdapat 3 orang Ibu bekerja yang berlaku sebagai subyek dalam tahap ini dimana peneliti menggunakan suatu pedoman pertanyaan mengenai latihan Yoga dan aspek kontrol diri serta tugas bagi para Ibu untuk mendapatkan hasil yang lebih mendalam.

Selain menggunakan metode wawancara, dalam penelitian kali ini peneliti juga menggunakan metode observasi dimana observasi adalah pengamatan dan pencatatan secara sistimatik terhadap unsur-unsur yang tampak dalam suatu gejala atau gejala-gejala dalam objek penelitian (Nawawi \& Martini, 1991). Dalam observasi ini peneliti berlaku sebagai orang luar yang turut serta dalam kegiatan subyek namun tidak semuanya. Hal ini terkait dari kenyamanan dan izin subyek serta izin dari tempat subyek bekerja. Hasil dari observasi ini akan peneliti laporkan dengan metode naratif dalam bentuk kalimat atau paragraf.

\section{Teknik Pengorganisasian dan Analisis Data}

Setelah mendapatkan data yang relevan, tahap yang selanjutnya dilakukan dalam penelitian ini adalah dengan melakukan analisis data dimana tahap yang pertama dilakukan adalah pengorganisasian data.

Dalam penelitian ini, pengorganisasian data dilakukan dengan pemberian kode yang merupakan suatu bagian integral dari analisi data dan dipandu berdasarkan pertanyaan penelitian (Ghony dan Almansur, 2012). Teknik coding yang digunakan peneliti adalah teknik analisis temantik 
dimana langkah awal adalah dengan melakukan open coding yaitu penguraian data tertulis dari verbatim dan catatan lapangan yang dilakukan untuk mencari segala kemungkinan makna yang dapat muncul. Tahap selanjutnya yang dilakukan peneliti adalah tahap axial coding dengan menyatukan kembali kalimat hasil dari pencarian makna pada open coding agar terlihat sebuah hubungan awal antar kategori awal pada penelitian ini. Tahap akhir adalah selective coding dimana pada tahapan ini peneliti merangkai suatu kalimat hasil temuan yang merupakan inti dari kalimat pada axial coding. Hasil dari tahapan ini akan disebut sebagai kategori inti dimana nantinya akan dilakukan pengecekan ulang pada subyek wawancara dan tenaga professional sehingga ketegori inti tersebut merupakan hasil dari rangkuman kenyataan di lapangan dan terlepas dari intrepetasi peneliti.

Setelah mengorganisasikan data tersebut peneliti akan menganalisis data menggunakan analisis deskriptif kualitatif dan interpretatif. Hal ini penting dilakukan dalam penelitian karena data merupakan konstruksi makna yang diperoleh dari sumber data dimana menganalisis data sama dengan mengontruksi dari kontruksi makna yang diperoleh (Kuntjara, 2006).

\section{Teknik Pemantapan Kredibilitas Penelitian}

Kredibilitas dalam penelitian kualitatif menggambarkan kecocokan konsep penelitian dengan konsepkonsep yang ada pada responden. Kredibilitas adalah istilah yang digunakan dalam penelitian kualitatif untuk menggantikan konsep validitas (Poerwandari, 2007). Dalam penelitian ini untuk mencapai kredibilitas peneliti mengacu pada pernyataan Sugiyono (2012) dimana pernyataan tersebut telah peneliti sesuaikan dengan penelitian yang akan dilakukan kali ini, yaitu:

- Memperpanjang pengamatan: dalam proses ini peneliti akan kembali mewawancara subyek dengan tujuan untuk semakin membentuk raport bagi subyek agar subyek maupun significant other terkait semakin nyaman dengan kehadiran peneliti sehingga didapatkan hasil yang maksimal. Disamping itu observasi pada subyek dan significant others juga akan dilakukan beberapa kali sehingga data yang didapat akan cukup untuk membuktikan hasil penelitian ini.

- Meningkatkan ketekunan: dalam proses ini peneliti akan melakukan pengamatan secara lebih cermat dan berkesinambungan. Peneliti juga akan kembali melakukan pengecekan antara data yang diperoleh dengan teori-teori terkait sehingga akan didapatkan deskripsi yang lebih akurat dalam penelitian ini.

- Triangulasi: dalam proses ini peneliti akan melakukan pengecekan data dari berbagai sumber dengan berbagai cara dan waktu. Dengan melakukan proses ini, menurut
Moleong (2005), peneliti dapat mengecek temuannya dengan jalan membandingkannya dengan berbagai sumber, metode atau teori lainnya. Dalam penelitian ini peneliti akan melakukan triangulasi data dengan metode pengumpulan data yang berbeda yaitu in depth interview dan observasi.

- Menggunakan bahan referensi: bahan referensi yang dimaksud dalam penelitian ini adalah bahan pendukung yang berguna untuk membuktikan data yang telah diperoleh oleh peneliti. Bahan pendukung yang digunakan dalam penelitian ini antara lain adalah kamera dan alat rekam suara sehingga data yang telah didapat dapat lebih dipercaya.

- Melakukan membercheck: dalam proses ini peneliti melakukan pengecekan data yang diperoleh kepada pemberi data dengan tujuan agar data yang ditulis dalam laporan nantinya sesuai dengan apa yang dimaksud subyek. Membercheck dalam penelitian ini akan dilakukan setelah didapatkan hasil data serta setelah peneliti melakukan proses koding data.

\section{HASIL PENELITIAN}

Berdasarkan temuan yang didapatkan pada saat preliminary study, observasi, dan in-depth interview, peneliti mendapatkan enam aspek kontrol diri yang terkait dengan latihan Yoga yang dijalani para Ibu bekerja dan mencakup pengetahuan, pengalaman serta perasaan para Ibu terkait dengan latihan Yoga, kontrol diri serta tugasnya sebagai seorang Ibu. Keenam aspek ini yaitu pengetahuan dasar individu mengenai latihan Yoga, perasaan individu terhadap latihan Yoga, pandangan individu terhadap peranan Ibu, pandangan individu terhadap kontrol diri individu, pengaruh peranan Ibu terhadap kontrol diri individu dan pengaruh Yoga terhadap kontrol diri. Sebelum mendapatkan keenam aspek kontrol diri ini, peneliti telah melakukan proses analisis tematik sehingga temuan-temuan dalam penelitian ini terbagi ke dalam beberapa tema. 


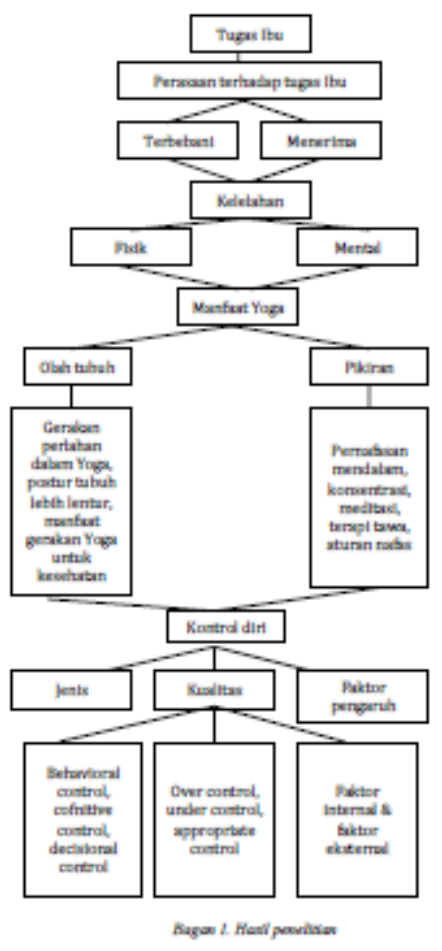

1. Pengetahuan Dasar Individu tentang Latihan Yoga

Jika dilihat dari pengetahuan subyek mengenai latiahn Yoga yang selama ini mereka jalani, ketiga subyek telah mengetahui definisi dari latihan Yoga tersebut dimana pada intinya mereka mengatakan bahwa Yoga merupakan sebuah latihan yang didalamnya terdapat olah fisik dan olah psikis yang berfungsi sebagai ketenangan jiwa. Ketiga subyek juga mengetahui manfaat yang diberikan oleh latihan Yoga tersebut dimana mereka menyatakan bahwa Yoga memiliki manfaat fisik seperti menyembuhkan maag, diabetes, kolesterol serta manfaat psikis yang berfungsi untuk ketenangan jiwa dan pikiran. Pengetahuan ini mereka dapatkan dari berbagai sumber seperti melalui buku, teman, instruktur Yoga serta melalui internet.

\section{Perasaan Individu terhadap Latihan Yoga}

Jenis gerakan Yoga secara umum yang biasa dilakukan oleh ketiga subyek adalah surya namaskar. Latihan Yoga juga bisa diikuti dengan berbagai terapi demi tercapainya suatu tujuan dari manfaat yang diinginkan masingmasing individu. Ketiga subyek mengalami kepuasan dalam menjalani latihan Yoga dimana hal ini didasarkan oleh manfaat yang mereka rasakan. Manfaat-manfaat yang dirasakan tersebut beragam mulai dari tubuh yang terasa lebih ringan, pikiran yang lebih tenang, berat badan yang stabil, dan lain-lain. Dengan dirasakannya manfaat-manfaat inilah individu tetap melaksanakan latihan Yoga demi tercapainya manfaat dan tujuan yang mereka inginkan secara maksimal.

\section{Pandangan Individu terhadap Peranan Ibu}

Dalam temuan ini ketiga subyek mengatakan bahwa seorang Ibu memiliki banyak tugas yang harus dilakukan, dimana tugas ini berupa tugas dalam keluarga maupun dalam lingkungan sosialnya. Banyaknya kegiatan yang harus dilakukan menimbulkan rasa malas dan terpaksa dalam diri individu. Disamping itu timbul juga perasaan segan dan tidak enak pada lingkungan sosial jika salah satu tugas dalam kegiatan itu diabaikan. Dengan banyaknya kegiatan yang harus dijalani, para wanita biasanya akan menentukan prioritas dalam setiap kegiatan tersebut. Dalam menentukan prioritas ini yang diutamakan ketiga subyek kegiatan yang membawa keuntungan demi kepentingan pribadi. Hal ini dikarenakan individu ingin menjaga kenyamanan dirinya dan keluarganya yang merupakan lingkungan terdekatnya terlebih dahulu. Setelah hal tersebut terpenuhi, barulah kemudian kepentingan akan hal-hal yang lain diutamakan.

\section{Pandangan Individu terhadap Kontrol Diri Individu}

Ketiga subyek telah mengetahui definisi dari kontrol diri dimana pada intinya mereka mengatakan bahwa kontrol diri adalah bagaimana seseorang dapat mengatur dirinya sendiri dalam segala aspek, baik perilaku maupun pikiran dengan mempertimbangakan segala konsekuensinya. Kontrol diri tidak hanya diperlukan pada emosi negatif seperti marah atau sedih, namun juga diperlukan saat perasaan sedang senang dan gembira.

Kontrol perilaku merupakan salah satu aspek yang paling terlihat dalam dinamika kontrol diri ketiga subyek dimana dalam penerapannya, responden memilah perilakunya sehingga dalam menghadapi stimulus, dimana responden dapat menentukan respon untuk menghadapi stimulus tersebut atau menghindarinya. Penentuan respon ini disesuaikan responden dari situasi dan kondisi saat itu. Penentuan respon atas stimulus yang terjadi ini juga didasarkan pada pengalaman yang dialami individu sebelumnya. Hal ini seperti proses pembelajaran yang membuat individu bisa memilih respon dengan cepat dengan mempertimbangkan konsekuensinya. Disamping itu, proses pengalaman dalam menentukan respon terhadap suatu stimulus bermula dari kemampuan responden dalam menentukan pilihan-pilihan. Responden menimbang segala pilihan atas respon yang akan ia lakukan dengan memperhitungkan konsekuensi dan untung rugi yang akan ia dapatkan sehingga dalam hal ini responden mengontrol dirinya dalam menentukan sebuah respon atas suatu stimulus.

Dengan kemampuan menentukan respon dan mengahadapi stimulus tersebut, subyek memiliki pandangan masing-masing terhadap kontrol dirinya. Dalam hal ini, semua responden merasa ada perubahan menjadi lebih baik dalam kontrol diri mereka meskipun perubahan ini beragam dan berbeda antara satu responden dengan responden yang lain. 
Perbedaan ini berupa perbedaan perubahan kualitas dari under control menjadi appropriate control maupun dari over control menjadi appropriate control. Perubahan kualitas kontrol diri ini dialami responden karena adanya beberapa pengaruh baik dari dalam maupun dari luar diri responden. Adapun pengaruh dari dalam diri adalah adanya keinginan responden untuk berubah, sedangkan pengaruh dari luar diri responden bersumber dari orang-orang terdekat responden seperti suami, anak atau sahabat responden.

\section{Pengaruh Peranan Ibu terhadap Kontrol Diri}

Banyaknya peranan seorang wanita sebagai Ibu membawa pengaruh terhadap kontrol diri responden. Hal ini berpengaruh pada tingkat kesabaran dan perhitungan responden dalam menentukan suatu respon pada satu stimulus. Status responden sebagai Ibu bekerja juga kerap kali mempengaruhi kontrol diri responden. Disamping itu timbul keinginan atau harapan akan keadaan repsonden saat ini dengan status responden sebagai Ibu bekerja dan kemampuan kontrol diri responden seperti keinginan untuk lebih dekat dengan anak, keinginan untuk lebih mensejahterakan keluarga hingga keinginan untuk berhenti bekerja nantinya.

\section{Pengaruh Yoga terhadap Kontrol Diri}

Responden merasa latihan Yoga yang mereka jalani merupakan salah satu faktor yang mempengaruhi kualitas kontrol diri mereka. Dalam hal ini repsonden merasa bahwa pengaruh dari latihan Yoga ini berasal dari latihan pernafasan dan meditasi yang termasuk dalam rangkaian latihan Yoga yang mereka jalani dimana dalam hal ini konsentrasi dalam setiap latihan nafas membuat mereka lebih sadar akan nafas sehingga menjadi kebiasaan dalam keseharian mereka dan membuat ketiga subyek lebih sadar akan perubahan emosi dan perasaan yang mereka rasakan.

\section{PEMBAHASAN DAN KESIMPULAN}

Penelitian ini bertujuan untuk mengetahui dinamika Ibu bekerja yang rutin menjalankan latihan Yoga dimana penelitian ini terkait dengan kontrol diri dan perasaan terhadap banyaknya tugas yang diemban sebagai seorang Ibu. Dalam penelitian ini peneliti juga ingin melihat bagaimana latihan Yoga tersebut membawa pengaruh bagi kontrol diri responden. Berdasarkan hasil penelitian yang telah dibahas sebelumnya, didapatkan bahwa terjadi perubahan kualitas kontrol diri bagi para Ibu setelah menjalankan latihan Yoga dimana perubahan ini disebabkan oleh latihan nafas dan meditasi yang tercakup didalamnya. Selain itu pengaruh dari orang terdekat serta responden sendiri juga turut mempengaruhi perubahan kualitas kontrol diri dalam diri responden.

Pentingnya kontrol diri ini difokuskan demi membawa responden ke arah yang lebih positif dimana sesuai dengan definisi kontrol diri yang dinyatakan oleh Goldfried dan Marbaum (dalam Muhid, 2009) bahwa kontrol diri dapat diartikan sebagai kemampuan untuk menyusun, membimbing, mengatur dan mengarahkan bentuk perilaku yang dapat membawa kearah konsekuensi yang positif. Dalam hal ini, kualitas kontrol diri Ibu bekerja yang menjalani latihan Yoga dapat digambarkan melalui bagaimana individu tersebut memodifikasi dan mengarahkan suatu perilaku menuju hasil yang diinginkan. Oleh karena itu, terdapat beberapa aspek yang berpengaruh dalam pembentukan kualitas kontrol diri seseorang.

1. Pandangan terhadap peranan Ibu

Banyaknya tugas sebagai Ibu pastilah menuai banyak pendapat termasuk dari Ibu sendiri. Pada Ibu bekerja, tuntutan dari tugas sebagai seorang Ibu menjadi bertambah dimana selain tugas untuk mengurus dan mengatur rumah tangga, mereka juga harus tetap terlibat dalam kewajiban kegiatan sosial disela-sela kesibukannya meniti karir. Menurut Bower (dalam Reynolds et.al, 2003) terdapat beberapa faktor yang mempengaruhi seorang Ibu untuk bekerja diantaranya faktor ekonomi, faktor sosial, politik dan demografi. Hal ini ditunjukkan bahwa beberapa responden lebih memilih untuk tetap bekerja dengan berbagai alasan, dimana diantaranya adalah untuk menghilangkan kejenuhan jika harus tetap dirumah, sebagai peningkatan status sosial serta karena adanya faktor ekonomi yang memaksa mereka untuk turut terjun dalam tugas mencari nafkah bagi keluarga.

Kesibukan akan menjadi seorang Ibu bekerja ini menuai beberapa pandangan dimana berbagai tugas ini dirasa cukup menyita waktu namun pandangan orang lainlah yang memaksa mereka untuk tetap menjalankan berbagai peranan tersebut. Dengan banyaknya tugas tersebut, para Ibu bekerja membuat penentuan prioritas akan kegiatan-kegiatan yang mereka lakukan dimana penentuan ini dimulai dari kepentingan pribadi dan keluarga kecil lalu berlanjut pada lingkungan sosial. Penentuan ini disebabkan karena keinginan para Ibu bekerja untuk memastikan bahwa diri serta keluarga kecil mereka aman dan untuk meminimalisir kerugian dan ketidakefektifan dari kegiatan-kegiatan yang dirasa kurang penting.

Banyaknya kegiatan sebagai seorang Ibu bekerja juga dapat menimbulkan kejenuhan dan kemalasan. Para Ibu bekerja akan memprioritaskan kegiatan yang dianggap bermanfaat bagi mereka namun beberapa kegiatan harus mereka ikuti karena adanya peraturan dan pandangan dari masyarakat akan hal itu. Kegiatan adat inilah yang terkadang menimbulkan keseganan bagi para Ibu bekerja karena disamping jadwal kerja yang padat, waktu pelaksanaan kegiatan adat seringkali tidak menentu sehingga banyak Ibu bekerja yang kesusahan mengatur jadwal libur. Hal ini menjadi masalah karena adanya penilaian dari masyarakat 
akan turut serta atau tidaknya seseorang pada kegiatan tersebut.

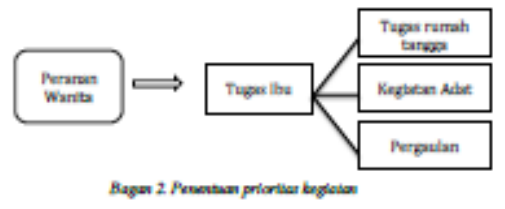

2. Aspek kontrol diri yang dipengaruhi oleh tugas sebagai Ibu

Banyaknya tugas seorang Ibu bekerja merupakan salah satu faktor pentingnya kemampuan kontrol diri terhadap diri Ibu tersebut. Menurut J.P Chaplin (1997), kontrol diri adalah kemampuan seseorang untuk membimbing tingkah laku sendiri, kemampuan untuk menekan atau merintangi impuls-impuls atau tingkah laku yang implusif. Dalam kata lain, kontrol diri adalah bagaimana seseorang dapat mengendalikan dirinya sendiri. Para Ibu bekerja yang mengikuti laithan Yoga disini memiliki tujuan untuk memperbaiki kontrol dirinya sehingga memutuskan untuk mengikuti latihan Yoga secara rutin.

Alasan pentingnya kontrol diri selain bagi diri sendiri dan keluarga adalah karena adanya dorongan dari masyarakat untuk selalu meningkatkan standar dirinya sehingga dibutuhkan pengontrolan diri agar tidak terjadi penyimpangan dalam peningkatan standar.

Kontrol diri memiliki beberapa aspek penting dimana yang pertama adalah kontrol perilaku yaitu dimana seorang individu dapat mengendalikan respon dari suatu stimulus dengan cara mempengaruhi atau memodifikasi suatu keadaan yang tidak menyenangkan.

Para Ibu bekerja telah melakukan hal ini dimana masing-masing responden telah memiliki cara sendiri dalam menghadapi suatu masalah baik itu masalah pada pekerjaan maupun masalah dalam keluarganya. Kemampuan menentukan respon ini dibuat berdasarkan pengalamanpengalaman yang telah terjadi sebelumnya dimana faktor ini termasuk dalam aspek kontrol kognitif.

Kontrol kongnitif merupakan kemampuan individu dalam mengolah informasi yang tidak diinginkan dengan cara menginterpretasi, menilai atau menghubungkan suatu kejadian kedalam suatu kerangka kognitif sebagai adaptasi psikologis untuk mengurangi tekanan yang dihadapi oleh individu (Averill, dalam Herlina, 2000).

Pengalaman akan suatu kejadian menunjukkan bahwa para Ibu bekerja menggunakan kontrol kognitif dalam menghadapi suatu situasi. Mereka belajar dari pengalaman sebelumnya dan menentukan respon yang tepat dan menguntungkan diri mereka. Pemilihan respon dari pengalaman ini merupakan kemampuan individu dalam memilih hasil tindakan berdasarkan apa yang disetujuinya.

Selain aspek-aspek diatas, terdapat beberapa faktor yang mempengaruhi kualitas kontrol diri seseorang yang dibagi menjadi dua yaitu faktor eksternal dan faktor internal. Faktor Internal adalah berbagai hal yang berasal dari dalam diri individu (Ghufron, 2003). Faktor internal dari para Ibu bekerja yang melakukan latihan Yoga adalah keinginan mereka untuk menjadi pribadi yang lebih baik dimana hal ini disebabkan adanya faktor eksternal yang mempengaruhi. Faktor eksternal yang mempengaruhi kesadaran Ibu bekerja akan pentingnya kontrol diri yang baik diantaranya adalah dorongan dari suami, anak-anak serta teman-teman responden dalam lingkungan sosial responden. Hal ini menyebabkan keinginan untuk peningkatan kontrol diri terus bertambah.

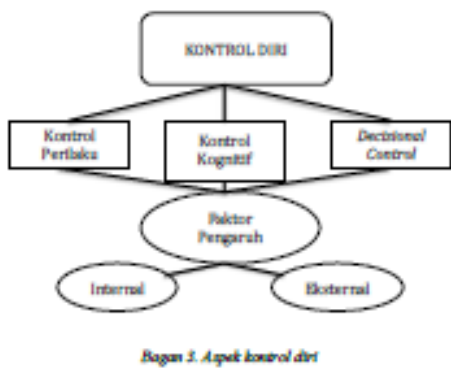

3. Pengaruh latihan Yoga terhadap kualitas kontrol diri

Yoga merupakan sebuah sistem kesehatan menyeluruh dimana melalui Yoga kita dapat mengenal tubuh, pikiran dan jiwa kita dengan lebih baik (Sindhu, 2007). Adanya faktor keseimbangan antara tubuh dan pikiran merupakan salah satu alasan para Ibu bekerja memutuskan untuk melakukan latihan Yoga. Hal ini dilakukan dengan berbagai tujuan diantaranya ingin menenangkan pikiran dan mendapatkan postur tubuh yang ideal.

Pengaruh dari latihan Yoga terhadap kontrol diri para Ibu bekerja ini dirasakan pada proses bernafas dan meditasi. Dengan kesadaran penuh akan nafas, kesadaran akan pikiran para Ibu menjadi terlatih sehingga lambat laun menciptakan suatu kebiasaan untuk memikirkan tindakan yang akan mereka ambil dengan pertimbangan konsekuensi yang ada.

Jeda yang diberikan oleh kebiasaan para Ibu bekerja yang melakukan latihan Yoga dalam bernafas ini menciptakan suatu ruang yang dirasakan manfaatnya bagi para Ibu sebagai waktu untuk memikirkan apa yang telah dan akan mereka perbuat. Dengan ini pengambilang keputusan menjadi tidak terburu-buru sehingga tidak menimbulkan kerugian yang tidak diinginkan.

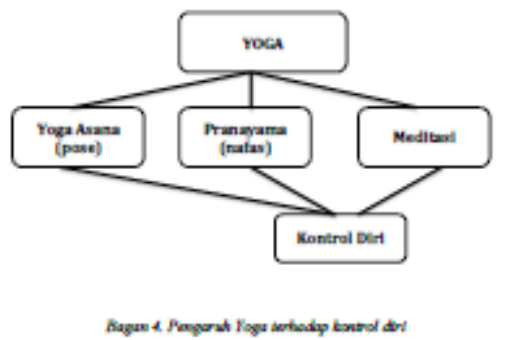


Berdasarkan hasil penelitian yang telah diuraikan diatas, maka dalam penelitian ini peneliti menarik kesimpulan dimana banyaknya tugas yang diemban para Ibu membawa pengaruh terhadap kontrol diri para Ibu. Hal ini disebabkan karena banyaknya tugas tersebut membawa rasa lelah dan jenuh bagi para Ibu sehingga kesibukan ini akan berpengaruh pada tingkat kontrol diri seseorang. Hal ini bisa dikatakan sebagai faktor eksternal dalam aspek kontrol diri yang mempengaruhi tingkatan kontrol diri seseorang. Disamping itu, para Ibu bekerja merasakan adanya perubahan pada kontrol dirinya setelah mereka melaksanakan latihan Yoga. Perubahan ini mengacu pada kualitas kontrol diri para Ibu dimana terdapat perubahan dari over control ataupun under control menjadi appropriate control. Teknik pranayama atau olah nafas pada latihan Yoga merupakan faktor yang mempengaruhi latihan Yoga dengan kontrol diri para Ibu.

Aspek kontrol diri yang dirasakan Ibu bekerja mencakup kontrol perilaku, kontrol kognitif dan kemampuan individu dalam memilih respon. Dalam hal ini kontrol diri individu dipengaruhi oleh individu sendiri dimana untuk menentukan prioritas dari respon yang dipilihnya para Ibu menentukannya berdasarkan keuntungan pribadi terlebih dahulu. Disamping itu peranan kontrol diri ini dianggap penting pagi para Ibu bekerja karena dengan memiliki kontrol diri yang baik, tindakan-tindakan yang tidak perlu dan dapat menyebabkan traumatik akan dapat dihindarkan.

Pada dasarnya, setiap penelitian memiliki beberapa keterbatasan sehingga hasil yang didapatkan tidak optimal. Begitupula yang terjadi dalam penelitian ini. Dalam pelaksanaannya, penelitian ini menemui beberapa kendala dan kesulitan dimana salah satunya adalah pencarian responden yang sesuai dengan kriteria yang telah ditetapkan peneliti sebelumnya. Hal ini dapat diatasi dalam penelitian selanjutnya dimana sebaiknya subyek yang digunakan juga mencakup pada Ibu tidak bekerja sehingga dapat memperkaya data dan hasil yang diperoleh. Keterbatasan lain juga dapat dilihat saat peneliti melakukan pengambilan data dimana terdapat beberapa aspek yang tidak tertangkap oleh peneliti dalam proses observasi sehingga untuk mengatasinya diharapkan peneliti selanjutnya lebih meningkatkan ketelitian dalam pengambilan data tersebut.

\section{DAFTAR PUSTAKA}

Ghony \& Almanshur. (2012). Metodologi penelitian kualitatif. Yogyakarta: Ar-ruzz Media

Ghufron. (2003). Hubungan kontrol diri dan persepsi remaja terhadap penerapan disiplin orang tua dengan prokrastinasi akademik. Jogjakarta: Fakultas Psikologi Universitas Gadjah Mada.
Harre \& Lamb. (1996). Ensiklopedi psikologi; pembahasan dan evaluasi lengkap berbagai topik, teori, riset dan penemuan baru dalam ilmu psikologi. Jakarta: Arcan.

Herlina Siwi, W. 2000. Hubungan kontrol diri dengan kecenderungan kecanduan

internet. Jogjakarta: Fakultas Psikologi Universitas Gadjah Mada.

Husserl \& Schutz. (1984). The limitations of phenomenology: Alfred Schutz's critical dialogue with Edmund Husserl. Journal: Husserl Studies.

J. P. Caplin. (1997). Kamus Lengkap Psikologi. Jakarta: PT Raja Grafindo Persada

Kuntjara. (2006). Penelitian Kebudayaan; Sebuah Panduan Praktis. Yogyakarta : Graha Ilmu

Lazarus, R. (1976). Patterns of adjustment 3rd edition. New York: McGraw-Hill.

Lerner. (2001). Encyclopedia of children's health. Dipetik 4 Februari 2013: www.healthofchildren.com

Moleong. 2005. Metodologi Kualitatif Edisi Revisi. Bandung: PT Remaja Rosdakarya

Muhid. (2009). Hubungan antara selfcontrol dan self-efficacy dengan kecenderungan perilaku prokrastinasi akademik mahasiswa fakultas dakwah IAIN sunan ampel Surabaya. Surabaya: Jurnal Ilmu Dakwah

Nawawi \& Martini. (1991). Penelitian terapan. Yogyakarta: Gadjah Mada University Press.

OECD. (2001). Labor Statistics: Working Mother. Dipetik 1 April 2013:

http://www.nationmaster.com/graph/lab_wor_mot-labor-workingmothers

Poerwandari, K. (1998). Penelitian kualitatif untuk penelitian perilaku manusia.

Jakarta: Lembaga Pengembangan Sarana Pengukuran dan Pendidikan Psikologi

(LPSP3) Universitas Indonesia.

Poerwandari, K. (2007). Pendekatan kualitatif untuk penelitian perilaku manusia. Jakarta: Lembaga Pengembangan Sarana Pengukuran dan Pendidikan Psikologi Fakultas Psikologi Univeritas Indonesia.

Reynolds, et.al. (2003). Motherhood, paid work and partnering: values and theories. Sage journals.

Santrock, J.W. (2006). Human adjustment. New York: McGraw-Hill Companies, Inc. 
Sindhu, P. (2007). Hidup sehat dan seimbang dengan yoga. Bandung: Mizan Media

Utama.

Somvir. (2008). Mari beryoga. Bali: Bali India Foundation.

Streubert \& Carpenter. (1999). Qualitative research in nursing: Advancing the humanistic imperative. Philadelphia: Lippincott

Sugiyono. (2012). Metode penelitian kuantitatif kualitatif dan R\&D. Bandung: Alfabeta

WHO. (2010). WHO Indonesia Health Profile. Dipetik 1 April 2013: http://www.ino.searo.who.int/en/Section3_158.htm 